\title{
A Case Study on Population Growth, Educational State and Energy Demand Analysis of Turkey by Logistic Equation and Fuzzy Sets Theory
}

\author{
Mustafa YILMAZ ${ }^{1,2}$, Humbat AHMADOV ${ }^{2,3}$ \\ Gaziantep University, Department of Informatics, 27310, Gaziantep, Turkey ${ }^{1}$ \\ Gaziantep University, Department of Engineering Physics, 27310, Gaziantep, Turkey ${ }^{2}$ \\ Institute of Radiation Problems, Azerbaijan Academy of Sciences, H. Javid Ave. Bakü, Azerbaijan ${ }^{3}$
}

\begin{abstract}
It is very important that the investigations and detailed interpretations of every statistical data afford the determination of the strategies for the future of nations and even the mankind. These strategies are then will be very powerful and make sense if the statistical data were used successfully. In this short study we want to analyze three major factors, population growth, energy demand and the educational state of Turkey which are responsible for the economical and social developments in the future of the country by use of the logistic equation for the estimation of the population growth and in the determination of the energy strategies for the future and the fuzzy sets theory for the educational state. It is a well known reality that industrially and economically developed countries are planning their energy production, social, political and economical strategies for the near and for the far future taking into the account of dynamical parameters of the world as a global village. Especially, if one thinks about the wars on the world during the end of the $20^{\text {th }}$ century this fact could be easily seen, even at the very beginning of $21^{\text {st }}$ century. The goals and the places of these wars are seen around natural energy resources of the $3^{\text {rd }}$ world, non-industrialized and economically poor, countries.
\end{abstract}

Keywords: Fuzzy Theory, Logistics Equation, Population, Education, Energy Demand.

\section{INTRODUCTION}

In this work we have tried to estimate the growth of the population of the country and then we would like to realize the important clusters in this population growth and depending on this investigations we also try to understand the demand in electrical energy, the consumption in order to shed some light for the future energy investments based on a national energy strategy. Also we try to show that the possibility of the use of logistic equation in development of self organizing systems such as population growth and energy demand analysis, and fuzzy theory [1] to define non-linear, indeterminate, and uncertain problems [2-6]. One could easily see that there is direct relation between the Grand National Product (GNP), the energy production and the energy consumption per people. It is known that, for a sustainable development, the investment of every 5 Cin the energy production returns as a $1 \$$ in the Grand National product for a country [7-10].

Table 1. Grand National Products versus the energy consumption for some countries in 1995 [10]

\begin{tabular}{|l|c|c|}
\hline Nations Grand National Energy Consumption \\
\hline Country & Product (US \$) & (equivalent coal, kg) \\
\hline USA & 26037 & 11372 \\
\hline Italy & 19121 & 4118 \\
\hline England & 18913 & 5315 \\
\hline Spain & 14111 & 3116 \\
\hline Iraq & 11308 & 1830 \\
\hline Syria & 3573 & 1278 \\
\hline Turkey & 1970 & 1232 \\
\hline China & 582 & 976 \\
\hline
\end{tabular}

The highest GNP per capita is, as seen in Table 1, for the USA and directly the highest energy production is also belongs to the same country $[7,10,11]$. If we then investigate the Turkey for the same year as given, the GNP is around 2000 US\$ and correspondingly the energy production is $1232 \mathrm{~kg}$, equivalent to coal which is a little below the figures of the neighboring countries Syria and Iraq [10-13].From this table we directly see that the energy production and the consumption is the one of the most important signature of the national development, and again if we take a look at the figure 3 , the energy consumption per people for a country also clarifies the above proposal.Keeping in mind the result of the values given in the Table 1, it is required for a country to increase the rate of development and being a leading country on a highly competing earth is possible only by the increasing in the energy investment.

\section{POPULATION GROWTH}

One can take the energy consumption per people as the key parameter, which depends on the population growth, for the countries development index. If a country makes good estimates of the population for the future then it could make good decision to reach and to keep these figures and make highly successful and strategical investments on the related fields.

The logistic equation, in that time, could be used to estimate the population growth (as system of naturally growing), which is defined; 


$$
\frac{d x}{d t}=\alpha x-\beta x^{2}
$$

where $\mathrm{x}$ is the population number, $\mathrm{t}$ is the time period, $\alpha$ and $\beta$ are some parameters. The general solution of this equation is

$$
x(t)=\frac{\alpha \cdot c}{\beta \cdot c+e^{-\alpha t}}
$$

Where $c$ is an integral constant, and in our case $\alpha>\beta>0$. A represents the increase and $\beta$ represents the decrease in the population.

If some unexpected and uncontrolled evidences, such as wars and epidemics are ignored, the above equation (Eq. 2) is very useful to find out the future trends of population by using some previous (past) exact values of the population to estimate the values of the parameters $\alpha, \beta$ and the constant c (see figure 1).

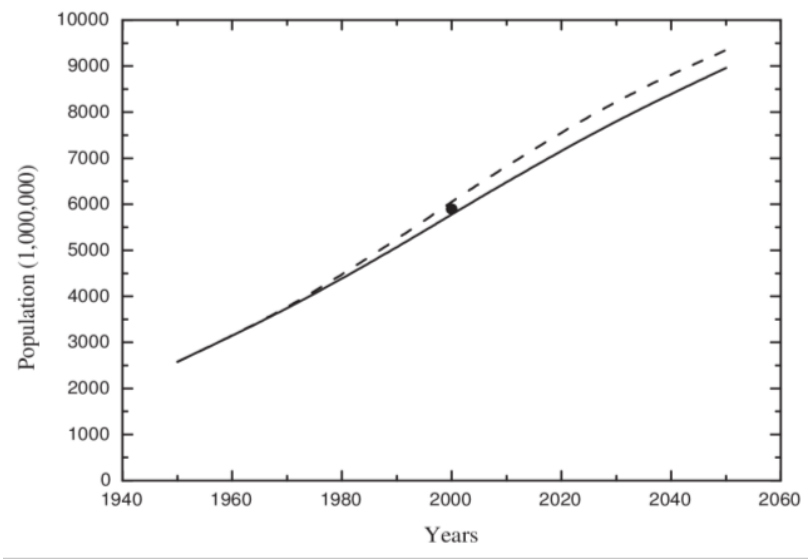

Figure 1. Estimated (solid) and real (dashed) world population growth upto 2050.

Using this method one can calculate the world population and compare it with previous estimations given in U.S. Bureau Of The Census 1997, as shown in figure 1. In the figure our calculations presented by a solid line and the results of estimations from U.S. Bureau Of The Census 1997 [14 ], are shown by dashed line.

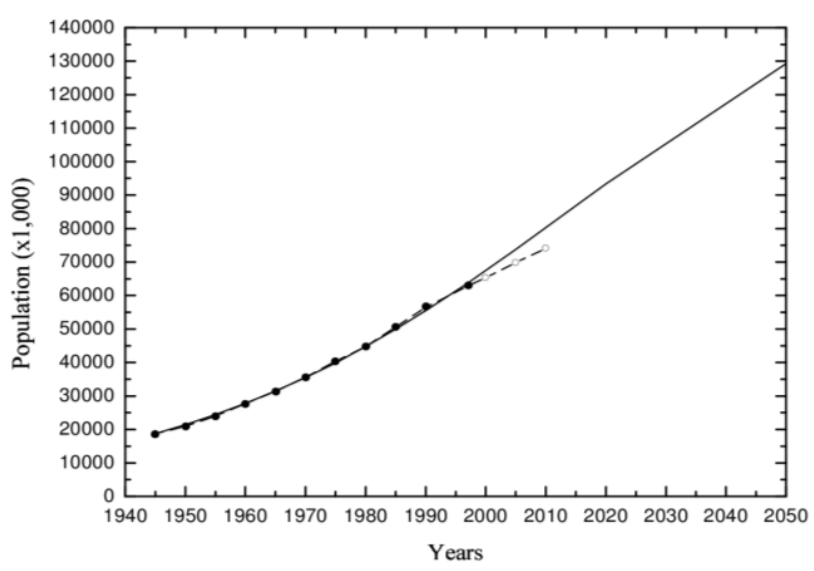

Figure 2. Real (dots), and forecasted-estimated (solid) population growth in Turkey.
Also we have shown the present world population for the year 2000 by a dot and as seen our result is in good agreement with it.

The same technique is used for the Turkey's population estimation by using $\alpha=0.03, \alpha \times c=21.05$, and $\beta \times c=0.12$ giving best fit with the exact values of the censuses between 1945-1997. Our results are presented in figure 2 as solid line and the results of censuses are presented as dots. Circles are the forecasting up to 2020 made by Turkish State Institute of Statistics, (TUİK), [12,13]. As it is seen clearly that the agreement of the result of the estimated values of logistic equation with the real data is a good base for being rely on trust in the values for the future years.

\section{ENERGY DEMAND}

Increasing the production of the energy and determination of a reliable policy for the energy is mainly depend on the governmental decisions, especially in the countries in which the investments in these fields are only done by the governments and are not allowed to the private companies. Our another goal is to use this technique to determine the demand trend on the energy production and then present some important key phenomenons that should be taken into account in the energy resources management and investment in the energy production. Our estimation on energy consumption per people and energy power per people, by use our population estimations, which were planned investments for 2010 and 2020 years (see Table 2) is coincide with those given by the Chamber of Mechanical Engineers [15-18], estimations. Turkey have been planning at least five nuclear power plants from 1970s [10] but have canceled the construction of the first NPP due to economical an political reasons for many years.

Table 2. Real [15-18] and estimated energy productions

\begin{tabular}{|c|c|c|c|c|}
\hline \multicolumn{5}{|c|}{ Present Total Energy Energy } \\
\hline Year & $\begin{array}{l}\text { Power } \\
(\mathrm{MW})\end{array}$ & $\begin{array}{l}\text { Consumption } \\
\text { (GWh) }\end{array}$ & $\begin{array}{c}\text { Consum } \\
\text { Ption per } \\
\text { people } \\
\text { (Kwh) }\end{array}$ & $\begin{array}{c}\text { Energy } \\
\text { Power } \\
\text { per people } \\
\text { (W) }\end{array}$ \\
\hline \multirow{4}{*}{1996} & 21247 & \multirow{4}{*}{95} & \multirow{4}{*}{1483} & \multirow{4}{*}{169} \\
\hline & $57 \%$ & & & \\
\hline & Thermal & & & \\
\hline & $\begin{array}{l}43 \% \\
\text { Hydro }\end{array}$ & & & \\
\hline 2000 & 30156 & 134 & 1900 & 217 \\
\hline \multirow{7}{*}{2010} & 65655 & \multirow{7}{*}{290} & \multirow{7}{*}{3500} & \multirow{7}{*}{400} \\
\hline & $57 \%$ & & & \\
\hline & Thermal & & & \\
\hline & $40 \%$ & & & \\
\hline & Hydro & & & \\
\hline & $3 \%$ & & & \\
\hline & Nuclear* & & & \\
\hline \multirow{6}{*}{2020} & 108770 & \multirow{6}{*}{547} & \multirow{6}{*}{5500} & \multirow{6}{*}{628} \\
\hline & $63 \%$ & & & \\
\hline & Thermal & & & \\
\hline & $28 \%$ & & & \\
\hline & Hydro & & & \\
\hline & $\begin{array}{l}9 \% \\
\text { Nuclear* }\end{array}$ & & & \\
\hline
\end{tabular}
and consumptions for present and for the future for Turkey. 
Nowadays the construction of the first one in Akkuyu district of Mersin with a Turkish and a Russian consortium, whose feasibility studies have been carried out since 1980s $[19,20]$, have been approved by the Turkish Parliament in 2015 and another one, second of the series in Sinop Inceburun by a Turkish and a Japanese consortium, is in the final stage of tender process.

It could, also, be made an appropriate analysis of required time for the energy production per people, quality, cost, region and climatic variables for highly beneficial energetic policy.

To study the place of Turkey on the energy power consumption per people in the world, let us investigate the energy consumption values in the well developed and developing countries for the year 1995 [12,13,21]. In figure 3 , the solid step-like line shows the distribution of population density versus the energy power consumption. Dashed line shows the average of the lowest energy power consuming portion $(0-500 \mathrm{~W})$ of the world population density (person per power) and dotted one shows another average portion of the world population who consumes more energy power $(500 \mathrm{~W}-4000 \mathrm{~W})$. A rough integral calculations show the population who lives in developed countries use more energy power (from $500 \mathrm{~W}$ to $4000 \mathrm{~W}$ ), the area under the dotted line, is around $10 \%$ of world population but their energy power consumption rate is around $20 \%$ of the total world energy power consumption. (Also see Table 3). In the contrary the consumed energy for those people living under developed and in the poor countries ( $90 \%$ of world population) has an energy power consumption of $80 \%$ of the total world.

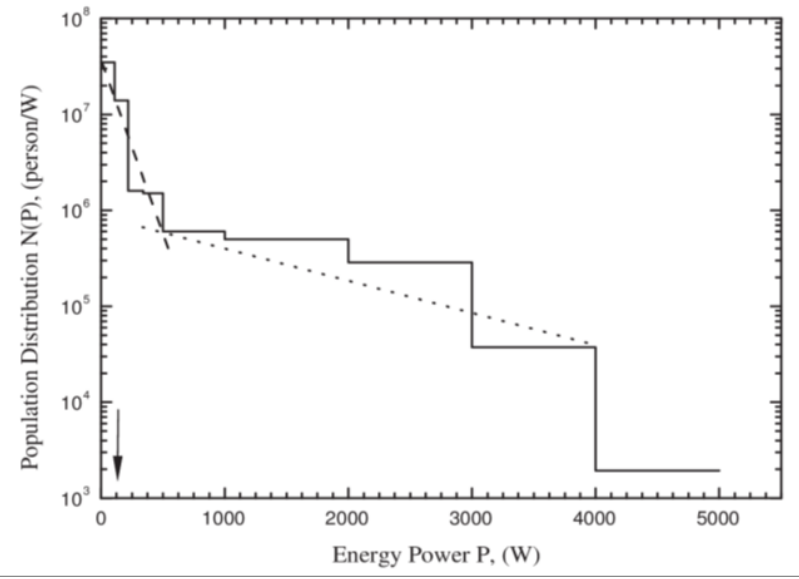

Figure 3. Distribution of world population over the electrical energy power consumption [21].

The calculation described above could be done by using

$$
d N=N(P) d P
$$

where $\mathrm{P}$ is the energy power, $\mathrm{dN}$ is the population, $\mathrm{N}(\mathrm{p})$ is the population density (people/W) corresponding to the energy power $\mathrm{W}$.

The consumption rate, $125 \mathrm{~W} /$ people in 1995, for the country which is pointed out by the arrow in the figure 3 and also figure 4 , well below the consumptions of the EC countries (See Table 3). The planned value by 2020 of the country is around $628 \mathrm{~W} /$ people and which is below the 1994 consumption values of the EC countries [21]. By using Turkey's natural resources, and inevitably by the nuclear power, we should compare our present situation with the European Countries and their consumption rates, since we should compete with them in every field of modern economical products and instruments. Table 3 shows the 1994 values, however, present trends clearly shows the values will be much higher than that value at 2020 .

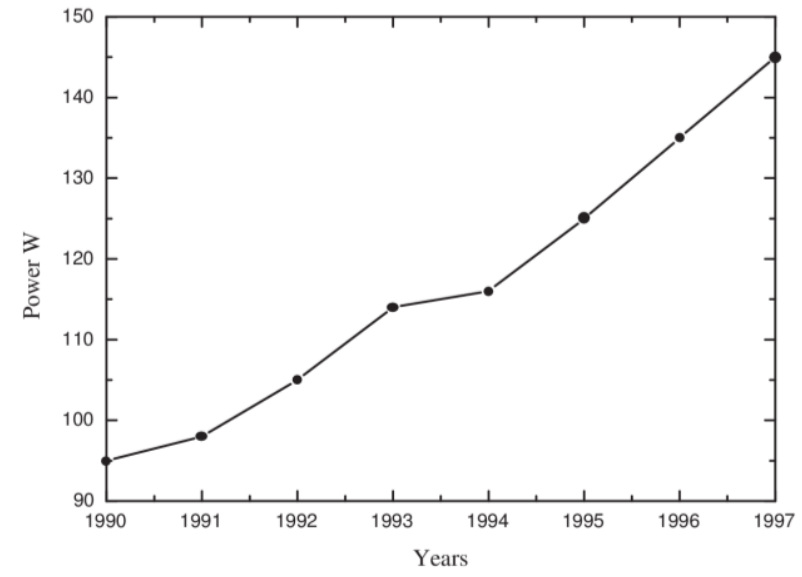

Figure 4. Change in energy consumption power per people in Turkey [13].

Table 3. Energy consumption per people in the world 1994 [16].

\begin{tabular}{|c|c|c|c|c|c|}
\hline \multicolumn{2}{|c|}{ World average } & \multicolumn{2}{c|}{ EC average } & \multicolumn{2}{c|}{ OPEC average } \\
\hline $\begin{array}{c}\text { Energy } \\
(\text { Kwh })\end{array}$ & $\begin{array}{c}\text { Power } \\
(\mathrm{W})\end{array}$ & $\begin{array}{c}\text { Energy } \\
(\text { Kwh })\end{array}$ & $\begin{array}{c}\text { Power } \\
(\mathrm{W})\end{array}$ & $\begin{array}{c}\text { Energy } \\
(\text { Kwh })\end{array}$ & $\begin{array}{c}\text { Power } \\
(\mathrm{W})\end{array}$ \\
\hline 2250 & 259 & 5762 & 647 & 7800 & 890 \\
\hline
\end{tabular}

\section{EDUCATIONAL STATE}

We tried to get a clear picture for the educational state of Turkey since it is the characteristic factor for the development measure. Fuzzy Sets Theory $[1,22]$ is used to analyze the educational state beside its use in many fields of science and technology [3].The results of the censuses of Turkey between 1985 through 1990 [12,13] are analyzed and presented, as sample data due to the ease of accessibility, below by using this versatile method.

Our aim, at first hand, was to classify the population for every five ages and determine the dominant population and educational age classes, and at the second, determine the amount of increase or decrease of this group in the following censuses, one after the other. In some cases similar analysis could be carried out by using simple statistical methods, but these statistical methods might be insufficient when the mentioned data are multidimensional or multivariable. For that reason the fuzzy sets theory becomes more adequate method.

The membership function, which is the most important concept of the fuzzy theory, will be determined for each of the age population group sets and for all the populations of each educated people group sets and the membership 
International Advanced Research Journal in Science, Engineering and Technology

Vol. 2, Issue 11, November 2015

Table 4. 1985 Turkey`s census results and membership functions.

\begin{tabular}{|c|c|c|c|}
\hline \multicolumn{5}{|c|}{1985} \\
\hline $\begin{array}{c}\text { Age } \\
\text { Group }\end{array}$ & $\begin{array}{c}\text { Age } \\
\text { Intervals }\end{array}$ & Population & $\begin{array}{c}\text { Membership } \\
\text { Function }\left(f_{N}\right)\end{array}$ \\
\hline 1 & $(20-25)$ & 4.784 .480 & 0,90 \\
\hline 2 & $(26-30)$ & 4.040 .762 & 0,86 \\
\hline 3 & $(30-34)$ & 3.374 .406 & 0,79 \\
\hline 4 & $(35-39)$ & 2.786 .571 & 0,62 \\
\hline 5 & $(40-44)$ & 2.208 .156 & 0,43 \\
\hline 6 & $(45-49)$ & 2.008 .609 & 0,38 \\
\hline 7 & $(50-54)$ & 2.042 .592 & 0,39 \\
\hline 8 & $(55-59)$ & 1.649 .069 & 0,29 \\
\hline 9 & $(60-64)$ & 1.130 .186 & 0,10 \\
\hline 10 & $(65-+)$ & 2.125 .908 & 0,40 \\
\hline & Total & 26.150 .739 & ---- \\
\hline
\end{tabular}

function of the intersection subsets of these sets to get the optimum, which will assign the highest value to the last membership function. The membership function could be given as [2,22],

$$
f(x)=1-\frac{1}{\alpha x+\beta}
$$

Where $\alpha$ and $\beta$ are some constants in such a way that their values will be determined for some definite values of the variable $x$.

Now, let us determine the membership function $(f(x))$ at definite $x$ values for the populations for each age and educational groups such that membership function is 0.9 at the maximum $x$ value and $f(x)=0.1$ at the minimum $x$ value. The mean value of $x$ could be calculated and then $f(x)=0.5$ could be set.

The values for the variable $\mathrm{x}$ tabulated for 1985 census, as an example, and their corresponding membership functions are presented in table 4 to calculate the constants, $\alpha$ and $\beta$. Using the table, the membership function $\mathrm{f}(\mathrm{x})=0.9$ for the maximum, $(x=4,784,480)$ and $f(x)=0.1$ for the minimum value $(x=1,130,186)$. The value of the membership function is 0.5 for the average $(x=2,615,073.9)$, as seen in the table.

Then the corresponding $\alpha=3.687 \times 10^{-6}$ and $\beta=-7.64$ could be calculated for the interval between the maximum and the average value of the variable. Similarly, $\alpha=5.986 \times 10^{-7}$ and $\beta=0.434$ for the interval between the average and the minimum value of the variable. Then the final form of the membership function by using the values of the constants, namely $\alpha$ and $\beta$, is then could be written as

$$
f_{N}(x)= \begin{cases}1-\frac{1}{5,986 \times 10^{-7} x+0,434}, & x_{\min } \leq x \leq x_{\text {aver }} \\ 1-\frac{1}{3,687 \times 10^{-6} x-7,64}, & x_{\text {aver }} \leq x \leq x_{\max }\end{cases}
$$

In the educational level and development relation context, one could consider the result of investigation [11,23-26], in which the number of the university students who are in the age range of (18-20) and registered to the programs related

Table 5. Age groups and membership function values for

\begin{tabular}{|c|c|c|c|}
\hline \multicolumn{4}{|c|}{1990} \\
\hline $\begin{array}{l}\text { Age } \\
\text { Group }\end{array}$ & $\begin{array}{c}\text { Age } \\
\text { Intervals }\end{array}$ & Population & $\begin{array}{l}\text { Membership } \\
\text { Function }\left(f_{N}\right)\end{array}$ \\
\hline 1 & $(20-25)$ & 5.095 .504 & 0,90 \\
\hline 2 & $(26-30)$ & 4.813 .127 & 0,88 \\
\hline 3 & $(30-34)$ & 4.086 .309 & 0,83 \\
\hline 4 & $(35-39)$ & 3.490 .064 & 0,73 \\
\hline 5 & $(40-44)$ & 2.788 .424 & 0,45 \\
\hline 6 & $(45-49)$ & 2.201 .159 & 0,32 \\
\hline 7 & $(50-54)$ & 2.018 .968 & 0,26 \\
\hline 8 & $(55-59)$ & 1.940 .521 & 0,23 \\
\hline 9 & $(60-64)$ & 1.615 .293 & 0,10 \\
\hline 10 & $(65-+)$ & 2.417 .363 & 0,37 \\
\hline & Total & 30.466 .732 & --- \\
\hline
\end{tabular}
1990 census data.

The result of the census of 1990 and the populations for each age group together with the membership function is presented in table 5, as an example, and correspondingly the final form of the membership function by using the values of the constants, again obtained in similar manner as explained for the previous case, is

$$
f_{N}(x)= \begin{cases}1-\frac{1}{6,21 \times 10^{-7} x+0,108}, & x_{\min } \leq x \leq x_{\text {aver }} \\ 1-\frac{1}{3,906 \times 10^{-6} x-9,899}, & x_{\text {aver }} \leq x \leq x_{\max }\end{cases}
$$

As seen from the membership functions the dominant age group lies between the ages 20-25 for the sample data of censuses 1985 and 1990.

The comparison of the membership functions for the years mentioned above shows that the population of Turkey is getting younger year after year according to the available presented data, which is very important result of this study. Consequently, the productive group, who are mostly below the 45 years of age, is decreased in the total population according.

The situation in the educational level, which is characterized by the membership functions of the educational shares of the age groups also calculated and presented in table 6. If one compares the membership functions for 1985 and 1990, it is clearly understood that the educational levels for the ages below 45 increases.

Therefore, as the younger population increases in Turkey, the educational level between the productive people, which lies between the medium and young people of the total population, also increases.

This result also shows us that the the increase in the life standards, or leaving in a high life standard, be possible only by a good education for the young people is seen by the Turkish people. 
to scientific and technical programs, is taken as the In order to find the dominant age group, since the measure of the development (1980), is found around 12\% importance of the number of the people who have a general to the population in that age group in developed countries. education, one should find the subset, $D=N \cap G$ of the This number lies around $2 \%$ in the muslim countries [26]. presented membership functions of the age groups, $f_{D}=f_{N} \wedge$ For the specific case our study, the number of the university $f_{G}=\min \left(f_{N}, f_{G}\right)$, where $N$ and $G$ are age and educational graduated young people in the age group (25-29) is seen groups respectively, and the results are tabulated in the $6 \%$ which could be taken as the corresponding age group in table 7 .

Turkey due to the available data of 1985 census.

Table6. Educated people age groups and corresponding membership functions for 1985 and 1990 censuses.

\begin{tabular}{|c|c|c|c|c|c|}
\hline \multirow{2}{*}{$\begin{array}{c}\text { Age } \\
\text { Groups }\end{array}$} & \multirow{2}{*}{$\begin{array}{c}\text { Age } \\
\text { Intervals }\end{array}$} & \multicolumn{2}{|c|}{1985} & \multicolumn{2}{|c|}{1990} \\
\hline & & $\begin{array}{l}\text { Educated } \\
\text { People }\end{array}$ & $\begin{array}{l}\text { Membership } \\
\text { Function }\left(f_{G}\right)\end{array}$ & $\begin{array}{c}\text { Educated } \\
\text { People }\end{array}$ & $\begin{array}{l}\text { Membership } \\
\text { Function }\left(f_{G}\right)\end{array}$ \\
\hline 1 & $(20-24)$ & 4.131 .732 & 0,90 & 4.563 .759 & 0,90 \\
\hline 2 & $(25-29)$ & 3.378 .590 & 0,86 & 4.228 .420 & 0,88 \\
\hline 3 & $(30-34)$ & 2.636 .448 & 0,80 & 3.468 .341 & 0,84 \\
\hline 4 & $(35-39)$ & 1.984 .097 & 0,66 & 2.773 .173 & 0,75 \\
\hline 5 & $(40-44)$ & 1.367 .637 & 0,43 & 2.017 .376 & 0,47 \\
\hline 6 & $(45-49)$ & 1.086 .990 & 0,37 & 1.408 .483 & 0,36 \\
\hline 7 & $(50-54)$ & 912.771 & 0,32 & 1.093 .061 & 0,27 \\
\hline 8 & $(55-59)$ & 646.610 & 0,22 & 894.354 & 0,21 \\
\hline 9 & $(60-64)$ & 377.754 & 0,10 & 615.607 & 0,10 \\
\hline 10 & $(65-+)$ & 427.974 & 0,12 & 644.845 & 0,11 \\
\hline \multicolumn{2}{|c|}{ Total } & 16.950 .603 & --- & 21.707 .439 & --- \\
\hline
\end{tabular}

Table 7. Educational levels of the age groups and corresponding membership functions for the censuses data of 1985 and 1990.

\begin{tabular}{|c|c|c|c|c|c|c|c|}
\hline \multirow{2}{*}{$\begin{array}{c}\text { Age } \\
\text { Group }\end{array}$} & \multirow{2}{*}{$\begin{array}{c}\text { Age } \\
\text { Intervals }\end{array}$} & \multicolumn{4}{|c|}{1985} & \multicolumn{3}{|c|}{1990} \\
\cline { 3 - 8 } & & $\left(f_{N}\right)$ & $\left(f_{G}\right)$ & $\left(f_{D}\right)=\left(f_{N}\right) \wedge\left(f_{G}\right)$ & $\left(f_{N}\right)$ & $\left(f_{G}\right)$ & $\left(f_{D}\right)=\left(f_{N}\right) \wedge\left(f_{G}\right)$ \\
\hline 1 & $(20-24)$ & 0,90 & 0,90 & 0,90 & 0,90 & 0,90 & 0,90 \\
\hline 2 & $(25-29)$ & 0,86 & 0,86 & 0,86 & 0,88 & 0,88 & 0,88 \\
\hline 3 & $(30-34)$ & 0,79 & 0,80 & 0,79 & 0,83 & 0,84 & 0,83 \\
\hline 4 & $(35-39)$ & 0,62 & 0,66 & 0,62 & 0,73 & 0,75 & 0,73 \\
\hline 5 & $(40-44)$ & 0,43 & 0,43 & 0,43 & 0,45 & 0,47 & 0,45 \\
\hline 6 & $(45-49)$ & 0,38 & 0,37 & 0,37 & 0,32 & 0,36 & 0,32 \\
\hline 7 & $(50-54)$ & 0,39 & 0,32 & 0,32 & 0,26 & 0,27 & 0,26 \\
\hline 8 & $(55-59)$ & 0,29 & 0,22 & 0,22 & 0,23 & 0,21 & 0,21 \\
\hline 9 & $(60-64)$ & 0,10 & 0,10 & 0,10 & 0,10 & 0,10 & 0,10 \\
\hline 10 & $(65-+)$ & 0,41 & 0,12 & 0,12 & 0,37 & 0,11 & 0,11 \\
\hline
\end{tabular}

\section{CONCLUSION}

As a result, the dominant age group is always seen between the ages (20-24) and it is independent of the shares of the age groups and the years. This suggests us that the number of the young people increases and their decisiveness on the importance of the education are getting higher than the previous generation and this result could be easily observed in the 1990 census result.

Education has also some levels inside itself, and the results containing such educational levels and the corresponding fuzzy set membership function values are presented in table 8, only for 1985 census data since its availability, and could be carried out for the data of later censuses.
As it is seen the dominant group based on their completed last schools in all the educational levels is again in the (20-24) age group except the university graduates which is at (25-29) and it is reasonable if we consider the education durations in the universities. However, regardless of this age difference, the most important result of our work remains unchanged.

As it is seen the Turkey's population is growing, and according to our presented estimates, especially the number of the young people is increasing as a dominant group in this total population so their needs will also increasing in every respects and should be taken in to account in all strategical decisions of the country. 
International Advanced Research Journal in Science, Engineering and Technology

Vol. 2, Issue 11, November 2015

Table 8. Completed last schools and age groups and corresponding membership functions for a sample census of 1985.

\begin{tabular}{|c|c|c|c|c|c|}
\hline \multicolumn{7}{|c|}{ Membership Functions } \\
\hline $\begin{array}{c}\text { Age } \\
\text { Interval }\end{array}$ & Population & $\begin{array}{c}\text { University } \\
\text { Graduates }\end{array}$ & $\begin{array}{c}\text { High } \\
\text { School } \\
\text { Graduates }\end{array}$ & $\begin{array}{c}\text { Secondary } \\
\text { School } \\
\text { Graduates }\end{array}$ & $\begin{array}{c}\text { Primary } \\
\text { School } \\
\text { Graduates }\end{array}$ \\
\hline$(19-24)$ & 0,90 & 0,61 & 0,90 & 0,90 & 0,90 \\
\hline$(25-29)$ & 0,81 & 0,90 & 0,79 & 0,77 & 0,83 \\
\hline$(30-34)$ & 0,73 & 0,87 & 0,63 & 0,68 & 0,77 \\
\hline$(35-39)$ & 0,54 & 0,77 & 0,44 & 0,49 & 0,64 \\
\hline$(40-44)$ & 0,41 & 0,47 & 0,33 & 0,35 & 0,44 \\
\hline$(45-49)$ & 0,37 & 0,32 & 0,23 & 0,21 & 0,39 \\
\hline$(50-54)$ & 0,38 & 0,20 & 0,19 & 0,19 & 0,35 \\
\hline$(55-59)$ & 0,28 & 0,17 & 0,16 & 0,17 & 0,23 \\
\hline$(60-64)$ & 0,10 & 0,10 & 0,10 & 0,10 & 0,10 \\
\hline$(65-+)$ & 0,40 & 0,14 & 0,11 & 0,14 & 0,12 \\
\hline
\end{tabular}

\section{REFERENCES}

[1] Zadeh, L. A., Fuzzy Sets, Information And Control, No: 8, 338, (1965).

[2] Mirzacanzade, A. H., Sultanov, C, A., Diakoptika Prosessov Nefteotdaci Plastov (Russian), Baku, Azerbaijan, 170-176, (1995).

[3] Tayal, V. K., Lather, J. S., and Sharma P. et. all., Power System Stability Enhancement Using Fuzzy Logic Based Power Systems Stabilizer, Third International Conference on Application of Fuzzy Systems and Soft Computing, Proceedings, 5-7 October 1998, 55-69, Wiesbaden, Germany (2013).

[4] Ying, L.-C. and Pan, M.-C., Using Adaptive Network Based Fuzzy Inference System to Forecast Regional Electric Loads, Energy Conversion and Management,Vol. 49, pp. 205-211, (2008).

[5] Pai, P. F., Hybrid Ellipsoidal Fuzzy System in Forecasting Regional Electricity Loads, Energy Conversion Management, Vol. 47, No. 15-16, pp. 2283-2289, doi:10.1016/j.enconman.2005.11.017, (2006).

[6] Liu, Y. C., Application of the Fuzzy Delphi Analytic Hierarchy Process on Rock Mass Classification, National Cheng Kung University, Tainan City, China (2002).

[7] Garrett, T. J., "Long-run Evolution of the Global Economy: 1. Physical Basis". Earth's Future Vol. 2, 3 : 127-151. doi:10.1002/2013EF000171, (2014).

[8] Öney, A., Dictionary of Economic and Commercial Phrases, Ankara, Turkey (Turkish), (1976).

[9] Nuclear Energy Agency - NEA/OECD, Nuclear Energy in a Sustainable Perspective, OECD Publications, 99, P 14, Paris, France, (1999).

[10] Turkish Atomic Energy Authority (TAEK), Sustainable Development and Nuclear Energy, Ankara, Turkey (Turkish), (2000).

[11] National Research Council (NRC), Electricity in Economic Growth, Energy, Washington, DC: National Academy Press (NAP). pp. 16, 40. ISBN 0-309-03677, (1986).

[12] Turkish State Institute of Statistics (TUIK) Social and Economic Characteristics of Population, Ankara, Turkey (Turkish), (1985).

[13] Turkish State Institute of Statistics (TUIK), 1999 Statistics Yearbook of Turkey, General Population Census,Turkey (Turkish), (2000).

[14] U.S Bureau Of The Census, Total Midyear Population For The World: 1950-2050, International Data Base, Washington, DC, U.S.A., (1997).

[15] Chamber of Mechanical Engineers (MMO), Energy and Environment, Proceedings, 5-7, Ankara, Turkey (Turkish), (1997)..

[16] International Atomic Energy Agency- IAEA, Key World Energy Statistics, Vienna, Austria (2004).

[17] International Atomic Energy Agency- IAEA Energy, Electricity and Nuclear Power Estimates for the Period of up to 2030, Vienna, Austria (2004).

[18] International Atomic Energy Agency, OECD/IAEA World Energy Outlook, Paris, France (2004).

[19] Turkish Ministry of Energy and Natural Resources, "Nuclear Power Plants Planned in (http://www.enerji.gov.tr/tr-TR/Sayfalar/Ulkemizde-Planlanan-Nuk leer-Santral-Projeleri) (Turkish), (2015).
[20] Turkish Atomic Energy Authority (TAEK) Akkuyu Nuclear power Plant Revised Feasibility Report Nr:3, Vol: 1-2, NSD-126, Ankara, Turkey (Turkish), (1980).

21] Putvinsky, S. V., Is the Future Peaceful System Possible without Nuclear Fusion?, UFN, No: 11, v. 168, (1998).

[22] Ross, T. J., (1995). Fuzzy Logic With Engineering Applications, Mcgraw-Hill Inc, New York.

[23] Hanushek, E. A., and Kimko, D. D., "Schooling, labor force quality, and the growth of nations." American Economic Review 90, no. 5 : 1184-1208, (2000)

[24] Hanushek, E. A., and Woessmann, L., "How Much Do Educational Outcomes Matter in OECD Countries?" Economic Policy, 26, no. 67: 427-491, (2011).

25] Paepke, C. O., The Evolution of Progress: The End of Economic Growth and the Beginning of Human Transformation. New York, Toronto: Random House. p. 109. ISBN 0-679-41582-3, (1992).

26] Salam, A., Edit. Lai, C. H. and Kidwai, A., Ideals and Realities,Selected Essays of Abdus Salam, $3^{\text {rd }}$ Ed., World Scientific Publishing, Singapore, (1989). 